Bangladesh J. Zool. 40(2): 197-205, 2012

\title{
FOOD HABITS AND FEEDING BEHAVIOUR OF SPOTTED FLAPSHELL TURTLE, LISSEMYS PUNCTATA (LACEPEDE, 1788) IN BANGLADESH
}

\author{
Md. Lokman Hossain*, Sohrab Uddin Sarker and Noor Jahan Sarker \\ Department of Zoology, University of Dhaka, Dhaka-1000, Bangladesh
}

\begin{abstract}
The study was conducted between March 1998 and February 2001 in nature and in captivity to observe the food habits and feeding behaviour of spotted flapshell turtle, Lissemys punctata (Lacepede, 1788) in Bangladesh. The species was found to be carnivore feeding on mollusks, annelids, crabs, insects, slow moving and diseased fish. In nature, the food consumption of the turtle was $0.47 \%$ of the body weight per day and that was the highest in rainy season $(0.70 \%)$ and lowest in winter $(0.15 \%)$. In captivity, the consumption was $8.2 \%$ of the body weight per day and it was the highest in rainy season $(11.8 \%)$ and lowest in winter $(3.9 \%)$. The feeding frequency was higher in captivity than in nature.
\end{abstract}

Key words: Food, feeding behaviour, spotted flapshell turtle, Bangladesh

\section{INTRODUCTION}

Turtles play an important role in the ecosystem by feeding on a variety of aquatic and semi-aquatic animals, viz. worms, insects, snails, slow moving aquatic crabs, dead animals and fragments of dead bodies, thus reduce the water pollution (Hossain and Sarker 1995). Turtle species are important in the control of aquatic larval and adult stages of aquatic insects, aquatic vertebrates, trash fish, mollusks, other detritus and beneficial organisms (Fugler 1984). Freshwater turtles perform a valuable service as scavengers in the ponds, rivers and stagnant water and thus keep the aquatic systems free from pollution (Rao 1985). The uncontrolled exploitation of the natural resources has increased significantly due to its commercial value in the present decade (Khan 1982). However, at present no strategic management plan is undertaken for any nonmarine turtle species of Bangladesh (Hossain 2000).

The flapsheel turtle, Lissemys punctata, has been studied by Vijaya (1981), Auffenberg (1981), Whitaker and Romulus (1997) and Deraniyagala (1953). All of them observed that the turtle species is carnivore in nature.

The present study was attempted to determine the food habits and feeding behaviour of the spotted flapshell turtle, Lissemys punctata, in nature and in captivity. The findings will help the future researchers to assess the possibility in establishing turtle farms in order to replenish the nature and also fulfill the market demands.

*Author for correspondence. Present address: National Academy for Educational Management, Dhanmondi, Dhaka-1205, Bangladesh. E-mail: drlokmanhossain@yahoo.com 


\section{MATERIAL AND METHODS}

The study was conducted between March 1998 and February 2001 in Chandpur, Naraynganj, Manikganj, Gopalganj and Madaripur districts and Zoological garden of Dhaka University, Dhaka, Bangladesh. Data were processed in computer software, MS Excel using statistical software SPSS (Version 10.0) and analysed by one way analysis of variance (ANOVA). Seasonal differences in food consumptions were tested by Chi-square test. Significance was tested at the $\mathrm{p}<0.05$ level.

Food habits and feeding behaviour in nature: A total of 50 stomach contents of L. punctata was collected from the wetlands of Matlab and Haziganj upazilas under Chandpur district; Sonargaon and Arihazar upazila under Narayanganj district; Shebalaya and Gopinathpur upazila under Manikganj district; Chanda beel of Gopalganj district; and Kashiani of Madaripur district. Moreover, 100 turtles were also dissected at Mirpur gudaraghat (Gazi Traders) and Tipu Sultan Road (Ahmed Impex Traders), Dhaka to know the qualitative and quantitative information on food habits. The turtle specimens were collected from the natural habitats to ascertain the food habits in nature. They were captured mainly at day time from open water area in the field and were anesthetized instantly. The stomachs of the turtles were dissected out in the field and then preserved in an airtight container. A solution of $5 \%$ formalin and $1 \%$ glycerin was used as preservatives. Of the turtles 18 specimens were captured in summer, 16 rainy and 16 in winter seasons. The qualitative analysis of food items was made. The stomach contents of each turtle were separated and washed in a Petridish and categorized into two groups: (a) animals and (b) unidentified groups, by examining under the microscope. The food items were identified at species level by consulting books, guides and specialists of the respective fields. The comparative study of the quality of consumed food by the turtle species was also made. Stomach content of individual turtle was measured following the quantitative analysis made by Hartley (1948). Feeding behaviour of the species was studied in three $\mathrm{km}^{2}$ areas of each selected Upazilas under Chandpur and Manikganj districts.

Feeding behaviour in captivity: Artificial culture condition was created in the Zoological garden, Department of Zoology, University of Dhaka; North Kamalapur, Dhaka; a turtle hatchery at Gopinathpur upazila in Manikganj district. Two mini ponds, one cemented tank, two enclosures, four earthen jars and six aquaria were used for rearing and observing the feeding behaviour of turtles. Thirty categories of food items were supplied for observing the food habits and feeding in captivity. The consumed amount of food was assessed by subtracting the excess foods after 24 hours from supplied foods. The percentage 
of food consumption in relation to body weight per day per individual was also calculated.

Food consumption in different season: Food consumption was calculated in different months and seasons, and was converted to percentage in relation to body weight. Regression analysis was made and seasonal difference was tested by Chi-square methods. The daily consumption was studied in all seasons throughout the study period to know the seasonal difference. The significant differences of the food consumption in nature and in captivity were tested by one and two way ANOVA. This analysis was made to test the hypothesis that the food consumption of different species in different seasons in relation to body weight was equal and the homogeneity of several means (Sokal 1969).

Food preference: The stomach contents collected from nature were analyzed through qualitative and quantitative methods. At least five stomachs were collected for each month and consumed food items were separated and made food preferences. In captivity, different type of food items was supplied adequately to observe food preference. This practice was repeated for different weight groups of turtles in different seasons of the year. Observation was made during day and at night.

\section{RESULTS AND DISCUSSION}

\section{Food habits in nature}

Qualitative analysis: A total of 14 food items was identified in the stomach contents of $L$. punctata. The turtle was identified as carnivore as because all the food items found in the stomach contents were aquatic, semi-aquatic and terrestrial animals and animal fragments (Table 1). The major food items were mollusks (46.8\%), arthropods (aquatic insects, crabs, prawns) (11.8\%), fish and fish bones (14.1\%), animal fragments and chicken viscera (17.2\%), amphibians (1.4\%) and annelids (9.6\%) (Fig. 1). Mollusks seem to be the major portion of their diet. Vijaya (1981), Hossain and Sarker (1993), and Rashid and Swingland (1997) mentioned that the turtle is totally carnivore. Das (1995), however, stated that the turtle preferred animal foods to plants in captivity, but in nature it fed on adult frogs, tadpoles, fish, crustaceans, snails, earthworm, carrions, insects and aquatic weeds. Das (1995) also mentioned that a captive turtle ate three hatchlings of Pungshura tecta. Smith (1931) and Fugler (1984) stated that it is carnivore, but mainly fed on trash fishes. Whereas, Minton (1966) observed in Pakistan that the turtle was eating aquatic vegetation. Barbour and Ernst (1989) stated it as omnivore. 
Table 1. Stomach contents of 50 specimens of Lissemys punctata collected from nature.

\begin{tabular}{lcccc}
\hline \multicolumn{1}{c}{ Food items } & $\begin{array}{c}\text { Frequency } \\
\text { of } \\
\text { occurrence } \\
\text { (No) }\end{array}$ & $\begin{array}{c}\text { Frequency of } \\
\text { occurrence } \\
(\%)\end{array}$ & $\begin{array}{c}\text { Total weight } \\
\text { of stomach } \\
\text { contents } \\
(\mathrm{g})\end{array}$ & $\begin{array}{c}\text { Occurrence } \\
\text { relation to } \\
\text { consumed } \\
\text { food (\%) }\end{array}$ \\
\hline Earthworm, Metaphire spp. & 22 & 44 & 34.5 & 9.69 \\
Apple snail, Pila globosa & 22 & 44 & 27.0 & 7.58 \\
Freshwater muscle, Lamellidens sp. & 14 & 28 & 38.0 & 10.67 \\
Freshwater snails, Bellamaya spp. & 47 & 94 & 73.0 & 20.51 \\
Garden snail, Asiatica fulico & 13 & 26 & 29.0 & 8.15 \\
Aquatic insects, Belostoma sp. & 06 & 12 & 17.5 & 4.92 \\
Carapace of prawn & 28 & 56 & 18.0 & 5.06 \\
Legs of crab & 28 & 56 & 24.5 & 6.88 \\
Mastacembalus puncalus & 7 & 14 & 10.0 & 2.81 \\
Fish bone & 25 & 50 & 19.5 & 5.48 \\
Fish muscles & 16 & 32 & 21.0 & 5.90 \\
Bones of frog & 10 & 20 & 5.0 & 1.40 \\
Chicken viscera & 08 & 16 & 12.0 & 3.37 \\
Animal fragments & 42 & 84 & 27.0 & 7.58 \\
\hline
\end{tabular}

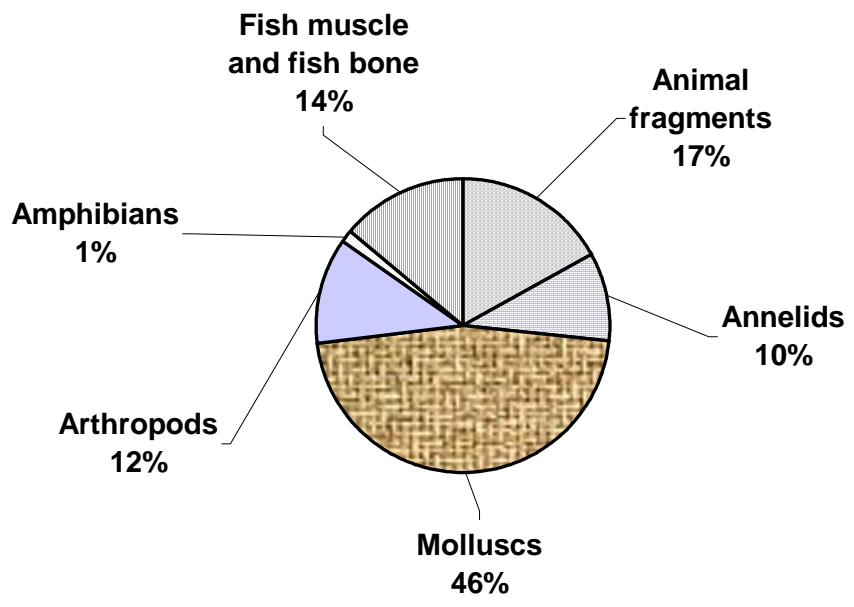

Fig. 1. Food consumption of Lissemys punctata in nature

Quantitative analysis: The amount of food items found in each stomach varied from 0.8 to $15.4 \mathrm{~g}$ (mean was $7.1 \pm 4 \mathrm{~g}$ ). The mean weight of dissected turtles was $1521.6 \pm 743.5 \mathrm{~g}$ (range 530 - $3500 \mathrm{~g}$ ). The food consumption was $0.47 \%$ in relation to mean body weight of the dissected turtles. The highest consumed food item identified was the freshwater snail, Bellamaya spp. $(20.51 \%)$ and the least consumed food item was M. puncalus $(2.81 \%)$. Bellamaya spp. was found in almost all the stomachs $(n=47)$ observed and only six stomachs contained aquatic insects (Belostoma sp.) (Table 1). 
In summer, rainy and winter seasons, 18,16 and 16 stomachs of $L$. punctata were analyzed, respectively, and 11, 14 and 14 food items were identified, respectively. The weights of the stomach contents in three seasons were 171, 152 and $33 \mathrm{~g}$, respectively, and their mean weights of the turtles were $1771.7 \pm$ $909 \mathrm{~g}, 1365.6 \pm 624 \mathrm{~g}$ and $1396.3 \pm 60 \mathrm{~g}$, respectively. Among the food items, Bellamiya sp. was common and found in 17 (94.4\%) stomachs in summer, whereas it was found in all stomach contents in rainy season. The food consumption varied from 6 to $13.5 \mathrm{~g}$ (mean $9.4 \pm 2.3 \mathrm{~g}$ ) in summer, 6.5 to $15.4 \mathrm{~g}$ (mean $9.5 \pm 2.1 \mathrm{~g}$ ) in rainy season and 0.8 to 3.5 (mean $2.1 \pm 0.9 \mathrm{~g}$ ) in winter. In the three seasons, the food consumption by the turtle was $0.54,0.70$ and 0.15 percents, respectively in relation to the mean weight of the turtles (Table 2). The highest food consumption was in May $(10.1 \pm 2.4 \mathrm{~g})$ during summer, in July $(12.2 \pm 1.9 \mathrm{~g})$ during rainy season and in February $(2.8 \pm 0.4 \mathrm{~g})$ in winter season. There was significant difference $\left(\chi^{2}=22.45, \mathrm{df}=11\right.$ and $\left.\mathrm{p}<0.05\right)$ of food consumption in different months of the year and also highly different $\left(\chi^{2}=5.19\right.$, $\mathrm{df}=2$ and $\mathrm{p}<0.01$ ) among three seasons.

\section{Food habits in captivity}

Qualitative analysis: Spotted flapshell turtle fed on only animal foods. They consumed 17 food items among the supplied mixed food items $(\mathrm{n}=35)$ during the study period of which major ones were Metaphire sp. Bellamaya sp., A. fulico, Lamellidens sp., Pila sp., Macrobrachium sp., N. nandus, Puntius sp., Mystus sp., Mastacembalus sp., poultry viscera etc.(Table 2).

Quantitative analysis: The mean weight of the consumed food per day varied between $0.8 \mathrm{~g}$ and $215 \mathrm{~g}$ (mean $59.2 \pm 45.8 \mathrm{~g}$ ) that was $8.2 \%$ in relation to the body weight of the reared turtles. The highest consumed food items were Bellamya sp. $(215 \pm 11.2 \mathrm{~g})$ and the least was Heteropneustes fossilis $(0.8 \pm 0.5$ g) (Table 2).

Seasonal variation: In three seasons, viz. summer, rainy and winter, the highest consumed food item was Bellamaya sp. (153.1 $\pm 12.4,215 \pm 15$ and 72.0 $\pm 5.4 \mathrm{~g}$, respectively) that was $21,29.5$ and 9.9 percents, respectively in relation to the mean body weight of the turtle reared in captivity, whereas the least consumed food item ( $H$. fossilis) per day in three seasons was $2.0 \pm 1.2 \mathrm{~g}$ in summer, $2.4 \pm 1.0 \mathrm{~g}$ in rainy season and $0.8 \pm 0.5 \mathrm{~g}$ in winter) that was $0.3,0.32$ and 0.10 percents, respectively in relation to mean body weight (Table 2).

The mean consumption of different food items in summer, rainy and winter months was $57.2 \pm 34.6,86.4 \pm 54.4$ and $28.16 \pm 19.5 \%$, respectively (Fig. 2) and that was $8.8,11.8$ and 3.9 percents, respectively in relation to their body 
weight. There was highly significant differences $\left(\chi^{2}=5.19\right.$, df $=2$ and $\left.p<0.01\right)$ in food consumption in different seasons in captivity.

Deraniyagala (1953) observed the turtle coming to shore at night and fed on carrion or decaying matters and other animal foods in Srilanka. Whitaker and Romulus (1997) stated that the turtle is omnivore and can be reared in captivity. $\mathrm{He}$ also reported that the species is hardly omnivorous and grows rapidly (Auffenberg 1981). It preys on living organisms, scavenges organic detritus from the pond bottom and household garbage. Vijaya (1981) observed that the turtle fed on earthworms, Racophorus maculatus, tadpoles, wasp and beetle. Present study confirms that it is absolutely carnivore.

Table 2. Seasonal variation of food consumption of Lissemys punctata in captivity.

\begin{tabular}{lcccccc}
\hline & \multicolumn{2}{c}{ Summer Season } & \multicolumn{2}{c}{ Rainy Season } & \multicolumn{2}{c}{ Winter Season } \\
\cline { 2 - 7 } \multicolumn{1}{c}{ Food Items } & Mean \pm SD & $\begin{array}{c}\text { \% body } \\
\text { wt. }\end{array}$ & $\begin{array}{c}\text { Mean } \\
\pm \text { SD }\end{array}$ & $\begin{array}{c}\text { \% body } \\
\text { wt. }\end{array}$ & $\begin{array}{c}\text { Mean } \\
\pm \text { SD }\end{array}$ & $\begin{array}{c}\text { \% body } \\
\text { wt. }\end{array}$ \\
\hline Metaphire spp. & $83.3 \pm 37.4$ & 11.4 & $156.7 \pm 13.1$ & 21.5 & $56.0 \pm 4.0$ & 7.7 \\
Lamelidens spp. & $84.0 \pm 36.0$ & 11.5 & $125 \pm 5$ & 17.1 & $29.0 \pm 3.0$ & 4.0 \\
Asiatina fulico & $30.0 \pm 8.9$ & 4.0 & $42 \pm 13.5$ & 5.6 & $23.4 \pm 4.1$ & 3.1 \\
Bellamaya spp. & $153.1 \pm 12.4$ & 21.0 & $215 \pm 15$ & 29.5 & $72.0 \pm 5.4$ & 9.9 \\
Pila globosa & $90.0 \pm 10.8$ & 12.3 & $141.3 \pm 16.7$ & 19.3 & $2.5 \pm 0.5$ & 0.3 \\
Macrobrachium spp. & $58.3 \pm 21.9$ & 7.9 & $88.7 \pm 9.6$ & 12.1 & $21.0 \pm 2.6$ & 2.9 \\
Clipisoma sp. & $45.0 \pm 5.0$ & 6.1 & $65 \pm 4.1$ & 8.8 & $18.3 \pm 1.2$ & 2.5 \\
Paratelphusa spinigera & $42.5 \pm 28.5$ & 5.9 & $47.5 \pm 5.6$ & 6.6 & $21.0 \pm 2.7$ & 2.9 \\
Amblypharyngodon mola & $82.5 \pm 4.0$ & 11.1 & $120 \pm 30$ & 16.2 & $62.5 \pm 2.5$ & 8.4 \\
Mastacembalus sp. & $24.3 \pm 3.8$ & 3.4 & $27 \pm 5.9$ & 3.6 & $10.5 \pm 1.1$ & 1.5 \\
Heteropneustes fossilis & $2.0 \pm 1.2$ & 0.3 & $2.4 \pm 1$ & 0.3 & $0.8 \pm 0.5$ & 0.1 \\
Channa punctata & $37.5 \pm 3.5$ & 5.3 & $39 \pm 13.5$ & 5.5 & $21.0 \pm 2.5$ & 2.9 \\
Mystus spp. & $63.0 \pm 13.0$ & 8.5 & $65 \pm 6.5$ & 8.8 & $13.5 \pm 1.1$ & 1.8 \\
Nandus nandus & $111.7 \pm 11.8$ & 15.6 & $150 \pm 8.2$ & 20.8 & $45.0 \pm 4.1$ & 6.3 \\
Puntius spp. & $66.3 \pm 10.2$ & 9.2 & $68.3 \pm 5.3$ & 9.5 & $20.7 \pm 2.5$ & 2.9 \\
Oriocromis nilotica & $55.0 \pm 7.9$ & 7.4 & $71.7 \pm 6.6$ & 9.6 & $30.0 \pm 4.9$ & 4.0 \\
Chicken viscera & $44.0 \pm 6.6$ & 6.3 & $44.8 \pm 5.2$ & 6.4 & $31.6 \pm 9.8$ & 4.5 \\
\hline
\end{tabular}

Comparison of food habits: The food consumption of the spotted flapshell turtle was $0.47 \%$ in nature and $8.2 \%$ in captivity in relation to body weight. The food consumption was recorded higher in rainy season followed by summer and winter seasons. Bellamaya sp. was the most favoured food item in summer and rainy season, and Metaphire sp. in winter.

In captivity, the highest consumption was in rainy season followed by summer and winter. Bellamaya sp. was the most favored food items in all seasons in captivity. There was a significant difference $(\mathrm{F}=8.723 \mathrm{df}=1 / 4$ and $\mathrm{p}<0.05)$ of food consumption in different seasons in captivity and in nature (Fig. 2). 
Feeding behaviour: In nature, the spotted flapshell turtle was found to feed on Metaphire sp. and insects by digging the soil with the help of snout, neck and forelimbs. The turtle moves to lands to catch garden snails and broken the shells with the help of bony shields like teeth and consumed the flesh.

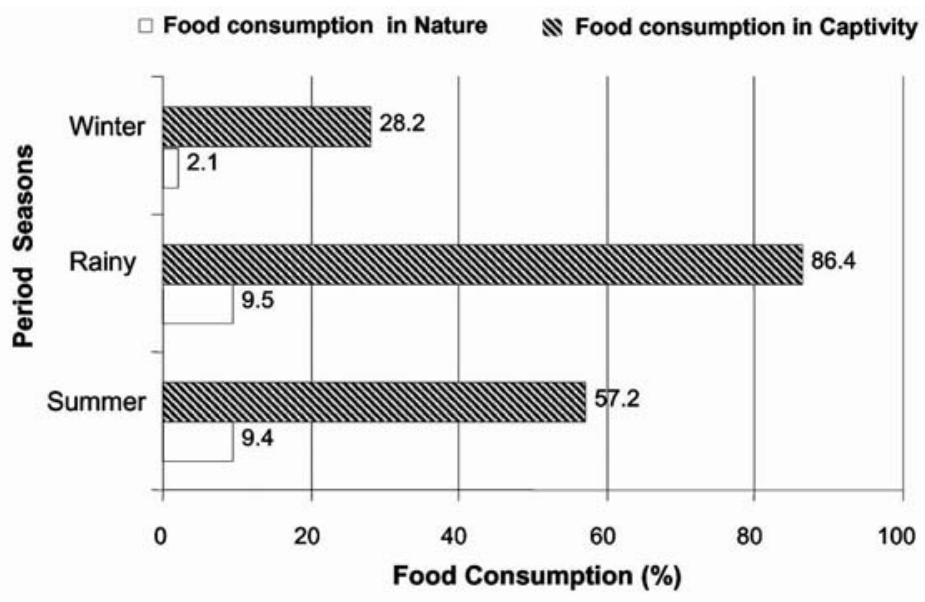

Fig. 2. Food consumption of L. punctata in relation to body weight.

In captivity, the turtle consumed only animal food items. The turtle became more active when water was changed in the aquaria and made water flow to accumulate the supplied foods into the corner of the aquaria, then began to eat directly with the help of jaws and forelimbs. Mollusk shells were crushed and muscles were consumed. Freshwater snails were taken and crushed the jaws and the muscular parts were consumed discarding the shells. Earthworms were consumed directly, cutting and tearing into pieces with jaws and limbs, and devoured chicken viscera. Soft fishes and fish entrails were picked up by extending its neck longitudinally in direction. In case of spiny fishes, such as Mystus sp., Clarius sp. and Heteropneustes sp. only muscles were consumed and spiny heads were rejected. After feeding, the turtle remained inactive for a while 4 to 5 minutes. In the enclosure, the turtle moved frequently around the fence in the morning and at night. In rainy days, the turtles were found moving in search for food on the grass beds and engulfed garden snails, broken the shells and ate the muscles only. In winter, the turtle remained in burrows at day time, and at night it came into water for feeding.

Food preference: On the basis of the analysis of stomach contents it was found that the most preferred food items were Bellamaya sp., Metaphire sp., benthos, poultry viscera, dead fish, garden snail, apple snail etc. In captivity, the 
turtle preferred slow moving animals or animal fragments. Some fast moving fishes like tilapia, lata fish, eel fish, etc. were released in the aquaria, cemented tank and mini ponds in the zoological garden. The turtle could not catch the fishes, but some diseased fishes were engulfed within a short time. The turtle refused all sorts of plants and plant products supplied in captive condition.

The spotted flapshell turtle is carnivore and feeds on natural available foods. The turtle used to have their food in aquatic and terrestrial habitats. So, it can be cultured as commercial purpose, but further research is essential in this regards.

\section{LITERATURE CITED}

ANNON. 2002. Export from Bangladesh 1980-2002. Export Promotion Bureau of Bangladesh. Matijheel C/A., Dhaka, Bangladesh. p. 77.

AUFFENBERG, W. 1981. Behaviour of Lissemys punctata (Reptilia, Testudinata, Trionychidae) in a drying lake in Rajasthan, India. J. Bombay Nat. Hist. Soc. 78(3): 487-493.

BARBOUR, R.W. and ERNSTS, C.H. 1989. Turtles of the World. Smithsonian Institution Press, Washington, DC, $313+$ xii pp.

DAS, I. 1995. Turtles and Tortoise of India. Oxford University Press, Bombay, 176+x pp.

DERANIYAGALA, P.E. 1953. A Coloured Atlas of some Vertebrates from Ceylon. Tetrapod : Reptilia 2: 26.

FUGLER, C.M. 1984. The commercially exploited Chelonia of Bangladesh. Taxonomy, Ecology, Reproductive biology and Ontogeny. Bangladesh Fish. Int. Bull. 2(1): 1-52.

HARTLEY, P.H.T. 1948. The assessment of the food of birds. Ibis 90: 361-381.

HOSSAIN, M.L. 2000. Wildlife in wetlands. A mission report on the status of wildlife in the floodplain areas, Bangladesh. IUCN - Bangladesh Country office, Dhanmondi, Dhaka, Bangladesh. 140 pp.

HOSSAIN, M.L. and SARKER, S.U. 1993. Freshwater turtles of Bangladesh. Bangla Academy Biggan Patrica 20(1): 109-120.

HOSSAIN, M.L. and SARKER, S.U. 1995. Ecology and food habit of Indian roofed turtle, Kachuga tecta in Bangladesh. Dhaka Univ. J. Biol. Sci. 4(1): 19-24.

KHAN, M.A.R. 1982. Chelonians of Bangladesh and their conservation. J. Bombay Nat. Hist. Soc. 79(1): 110-116.

MINTON, S.A. 1966. A contribution to the herpetology of West Pakistan. Bull. Amer. Mus. Nat. Hist. 134: 27-184.

MOLL, E.O. 1986. Survey of the freshwater turtles in India. Part-1. The Genus Kachuga J. Bombay Nat. Hist. Soc. 83: 538-552.

RAO, R.J. 1985. Management of crocodiles and turtles in wetland sanctuaries, India. Tigerpaper. 12(4): $1-5$.

RAO, R.J. 1987. Ecological studies on Indian turtles, Tigerpaper 14(3): 21-25. 
RASHID, S.M.A. and SWINGLAND, I.R. 1997. On the ecology of some freshwater turtles in Bangladesh. Proceeding on Conservation Restoration and Management of Tortoise and Turtles. An Int. Conf. Turtle and Tortoise Society, USA. pp. 225-242.

RASHID, S.M.A. and KHAN, S.M.M.H. 2000. Trade and conservation status of freshwater turtles and tortoises in Bangladesh. Asian Turtle Trade. Chelonian Res. Monographs 2: 77-85.

SANDRA, A. and DANIELA, F. 2000. Asian turtles are threatened by extinction. Turtle and Tortoise Newsletter 1: 1-9.

SMITH, M. A. 1931. The Fauna of British India including Ceylon and Burma; Reptilia and Amphibia, Taylor and Franchis London. 1: 179.

VIJAYA, J. 1981. Successful Artificial Breeding of Lissemys punctata Granosa (Smith) J. Bombay Nat. Hist. Soc. 79: 210-211.

WHITAKER, R. and ROMULUS. 1997. Turtle rearing in village ponds. Conservation, Restoration and Management of turtles and tortoises. An Int. Conf. (Abstract). New York, USA. 53 pp.

(Manuscript received on October 1, 2011; revised on July 20, 2012) 